\title{
New benzenesulphonohydrazide derivatives as potential antitumour agents
}

\author{
ŁUKASZ POPIOŁEK ${ }^{1}$, MONIKA GAWROŃSKA-GRZYWACZ ${ }^{2}$, ANNA BERECKA-RYCERZ ${ }^{3}$, \\ KINGA PARUCH $^{1}$, IWONA PIĄTKOWSKA-CHMIEL ${ }^{2}$, DOROTA NATORSKA-CHOMICKA ${ }^{2}$, \\ MARIOLA HERBET $^{2}$, ANNA GUMIENICZEK ${ }^{3}$, JAROSŁAW DUDKA ${ }^{2}$ and MONIKA WUJEC ${ }^{1}$ \\ ${ }^{1}$ Department of Organic Chemistry, Faculty of Pharmacy, Medical University of Lublin, 20-093 Lublin; \\ Departments of ${ }^{2}$ Toxicology and ${ }^{3}$ Medicinal Chemistry, Faculty of Pharmacy, \\ Medical University of Lublin, 20-090 Lublin, Poland
}

Received January 15, 2020; Accepted June 25, 2020

DOI: $10.3892 / \mathrm{ol} .2020 .12047$

\begin{abstract}
Cancer treatment remains a serious challenge worldwide. Thus, finding novel antitumour agents is of great importance. In the present study, nine new benzenesulphonohydrazide derivatives (1-9) were synthesized, and the chemical structures of the obtained compounds were confirmed by spectral analysis methods, including $\mathrm{IR},{ }^{1} \mathrm{H}$ nuclear magnetic resonance (NMR) and ${ }^{13} \mathrm{C}$ NMR. Experimental lipophilicity values were established using reversed phase-high performance thin layer chromatography. The antiproliferative activity of the synthesized compounds was tested against three tumour cell lines (769-P, HepG2 and NCI-H2170) and one normal cell line (Vero). Among the newly developed molecules, compound 4 exhibited generally the highest cytotoxicity across all tumour cell lines, and it was highly selective. However, higher selectivity towards the tested cancer cell lines was observed using compound 2 , when compared with compound 4 , which also exhibited significant antiproliferative activity against these tumour cells. In 769-P cells, compounds 5 and 6 were the most selective among all tested compounds. Compound 5 exhibited high cytotoxicity with an estimated $\mathrm{IC}_{50}$ value of $1.94 \mu \mathrm{M}$. In the NCI-H2170 cell line, compound 7 was the most cytotoxic and the most selective. In brief, the combination of fluorine and bromine substituents at the phenyl ring showed the most promising results, exerting high cytotoxicity and selectivity towards cancer cells. The renal adenocarcinoma cell line (769-P) appeared to be the most sensitive to the anticancer properties of the novel benzenesulphonohydrazones.
\end{abstract}

Correspondence to: Dr Łukasz Popiołek, Department of Organic Chemistry, Faculty of Pharmacy, Medical University of Lublin, 4A Chodźki Street, 20-093 Lublin, Poland

E-mail: lukasz.popiolek@umlub.pl

Key words: benzenesulphonohydrazide derivatives, MTT assay, antitumour activity, 769-P, HepG2, H2170, Vero, lipophilicity

\section{Introduction}

In 2018, $>1.7$ million cancer deaths worldwide were caused by lung cancer that remains the most common cancer (11.6\% of all cancers) and the main cause of cancer-related deaths (1). In USA in 2018, the number of lung cancer-related deaths exceeded the combined number of deaths caused by the most common cancers (breast, colon and prostate) (2). Lung cancer is a leading cause of cancer mortality for both men and women (2). The majority of neoplasms developing in the lungs are pathologically categorized as non-small cell lung cancer (NSCLC) and further divided into the following subtypes: Adenocarcinoma, large cell carcinoma and squamous cell carcinoma (SCC). Epidemiological data have demonstrated that $\sim 20 \%$ of NSCLC cases are diagnosed as SCC (1). It has been demonstrated that SCC is associated with chronic tobacco exposure (3).

Despite the advances in cancer treatment, liver and kidney tumours are also associated with high fatality rates (4-6). Liver cancer remains the sixth most diagnosed cancer globally and the second leading cause of cancer-related death worldwide (7). Liver cancer is more common among men compared with women, worldwide (4). The most important risk factors for developing liver cancer are hepatitis B and C infections, liver cirrhosis resulting from viral hepatitis, alcohol abuse and non-alcoholic fatty liver disease (NAFLD) $(4,8)$. Recently, the age-standardized incidence rate of primary liver cancer cases increased in men with age at diagnosis $\geq 60$ years, from 241,189 in 1990 to 578,334 in 2017, globally (8). Therefore, more preventive measures should be taken to prevent NAFLD from being the most important risk factor of liver cancer in elderly patients (9). However, in children, during the first years of life, liver neoplasms of an embryonal origin have been diagnosed (5). Treatment of advanced stages of liver cancer remains a large problem. Among a number of drugs that are currently under development, a multikinase inhibitor appears to be the most beneficial (4).

Renal cell carcinoma (RCC), which accounts for $90 \%$ of kidney cancer cases, is the most lethal among urological tumours (6), which is associated with the fact that $20-30 \%$ cases of RCC are diagnosed at a metastatic stage (9). The treatment 
of metastatic RCC remains a challenge, and the neoplasm at this stage is practically incurable (10).

Considering the dismal prognosis of patients diagnosed with metastatic RCC, advanced SCC or liver cancer, developing novel drug candidate molecules is important to improve the outcomes in these diseases. Thus, the present study focused on new benzenesulphonohydrazide derivatives. Benzenesulphonohydrazide derivatives have been reported to exert various biological activities, including antitumour $(11,12)$, antimicrobial (11-17), anti-inflammatory $(12,18)$ and analgesic activity (18). Benzenesulphonohydrazide derivatives such as benzenesulphonohydrazones are similar in structure to hydrazide-hydrazones (19), which are of interest to medicinal chemists due to their antimicrobial (20-23) and antitumour (24) activities. Biological activity is associated with lipophilicity, a physicochemical property of compounds that describes the balance between hydrophobicity and polarity (25). According to the IUPAC definition, lipophilicity is the affinity of a compound or moiety for a lipophilic environment (25), and it contributes to the absorption, distribution, metabolism, excretion and toxicity properties of a drug (26). According to Lipinski et al (27), the limit of $\log \mathrm{P}<5$ is a desirable lipophilicity range for potential drug candidates. However, previous studies have suggested that the range of $\log \mathrm{P}$ between 1 and 3 is optimal to ensure the desired physiochemical properties of the molecule $(28,29)$. Various methods may be used for either measuring or estimating lipophilicity, including traditional shake-flask method, various chromatographic methods, as well as, various computational methods. Some properties of the molecules can be characterized by the chromatographic retention data derived from their distribution between the stationary and mobile phases. In particular, reversed phase liquid chromatography (high performance liquid chromatography or thin layer chromatography) is frequently used for characterizing the lipophilic nature of different substances $(30,31)$.

The present study aimed to design, synthesize and analyse new benzenesulphonohydrazones to identify potential novel antitumour agents for RCC, SCC and liver cancer.

\section{Materials and methods}

Chemistry. The reagents and solvents used in the present study were purchased from Sigma-Aldrich; Merck KGaA and were used without further purification. The melting points were determined using the Fisher-Johns blocks melting point apparatus (Thermo Fisher Scientific, Inc.) and left uncorrected. Fourier transform infrared spectra were recorded on a Nicolet 6700 spectrometer (Thermo Fisher Scientific, Inc.), $v$ in $\mathrm{cm}^{-1} .{ }^{1} \mathrm{H}$ nuclear magnetic resonance (NMR) and ${ }^{13} \mathrm{C}$ NMR spectra were recorded on a Bruker Avance 300 apparatus (Bruker Corporation) in DMSO- $d_{6}$, with tetramethylsilane (TMS) as the internal standard. Chemical shifts were reported in ppm $(\delta)$, with TMS as the standard reference, whereas coupling constants $(J)$ were reported in Hz. Mass spectra were recorded using a microTOF II spectrometer (Bruker Corporation) in $\mathrm{m} / \mathrm{z}$. The progress of the reaction and the purity of the obtained compounds were monitored by thin layer chromatography using pre-coated with silica gel aluminium sheet 60 F254 plates (Merck KGaA) in $\mathrm{CHCl}_{3} / \mathrm{C}_{2} \mathrm{H}_{5} \mathrm{OH}(10: 1, \mathrm{v} / \mathrm{v})$ as the solvent system. Spots were detected by exposure to UV light at $254 \mathrm{~nm}$. Elemental analysis of the obtained compounds was performed with the AMZ 851 CHX analyser (Gdansk University of Technology).

Synthesis of benzenesulphonohydrazones. 4-Methylbenzenesulphonohydrazide $(0.01 \mathrm{~mol})$ was dissolved in $10 \mathrm{ml}$ $96 \%$ ethanol, and an appropriate substituted aromatic aldehyde $(0.011 \mathrm{~mol})$ was added. The mixture was heated under reflux for $3 \mathrm{~h}$. Then, the solution was allowed to cool down. Subsequently, the formed precipitate was filtered off under low pressure and recrystallized from ethanol. Detailed physico-chemical information of the synthesized benzenesulphonohydrazones 1-9 is presented in Supplementary Materials and methods (Data S1).

Lipophilicity. The experimental lipophilicity of the synthesized benzenesulphonohydrazide derivatives 1-9 (Table I) was determined using reversed-phase thin-layer chromatography on RP-18 silica gel plates from Merck (Merck KGaA) (Tables SI and SII). Determination of the lipophilicity parameters was performed as previously described $(23,24,30,31)$ and presented in the Supplementary Materials and methods (Data S1). Additionally, the calculated lipophilicity of the compounds 1-9 was obtained using ALOGPS 2.1 software $(32,33)$ and is presented in Table SIII.

Cell lines and culture conditions. The present study used tumour cell cultures supplied by the American Type Culture Collection (ATCC), including 769-P (human renal cell adenocarcinoma; ATCC ${ }^{\circledR}$ CRL-1933 ${ }^{\mathrm{TM}}$ ), HepG2 (human liver cancer; ATCC $\left.{ }^{\circledR} \mathrm{HB}-8065^{\mathrm{TM}}\right)$, NCI-H2170 (H2170; human squamous cell carcinoma of the lung; $\left.\mathrm{ATCC}^{\circledR} \mathrm{CRL}-5928^{\mathrm{TM}}\right)$, as well as Vero cells (monkey kidney; ATCC ${ }^{\circledR} \mathrm{CCL}^{-81^{\mathrm{TM}}}$ ), which was used as a normal reference cell line in similar biological activity-focused studies (34-36). The HepG2 and Vero cell lines were cultured in Eagle's minimal essential medium (EMEM; ATCC), whereas 769-P and H2170 cells were cultured in rich-component RPMI-1640 medium (containing L-glutamine, sodium pyruvate, glucose, HEPES and sodium dicarbonate). For all cells, the media were supplemented with $10 \%$ foetal bovine serum (FBS), $100 \mathrm{U} / \mathrm{ml}$ penicillin, $100 \mu \mathrm{g} / \mathrm{ml}$ streptomycin and $2.5 \mu \mathrm{g} / \mathrm{ml}$ amphotericin B. RPMI-1640, FBS, antibiotics and trypsin solution (trypsin $0.25 \% / E D T A$ $0.02 \%$ in PBS w/o $\mathrm{Ca}, \mathrm{Mg}$ with phenol-red) were supplied by PAN-Biotech $\mathrm{GmbH}$. The cells were cultured in $75-\mathrm{cm}^{2}$ tissue culture flasks (EasYFlasks ${ }^{\mathrm{TM}}$ Nunclon $^{\mathrm{TM}} \Delta$; Nalge Nunc International; Thermo Fisher Scientific, Inc.) as a monolayer in a humidified atmosphere with $5 \% \mathrm{CO}_{2}$ at $37^{\circ} \mathrm{C}$ in a cell incubator. Cell suspensions were prepared at a density of $1 \times 10^{5}$ cells $/ \mathrm{ml}$ and transferred to 96 -well cell culture plates (Wuxi NEST Biotechnology Co., Ltd.). The plates were incubated for $24 \mathrm{~h}$ in order to achieve cell adhesion. The following chemicals were also used: MTT (Sigma-Aldrich; Merck KGaA), DMSO (Avantor Performance Materials Poland S.A.) and PBS (Biomed Lublin S.A.).

Cell proliferation inhibition assay. The inhibitory effects of compounds 1-9 on cell proliferation were assessed by MTT assay [DB-ALM Protocol no. 17: MTT Assay; European Union Reference Laboratory, European Center for the 
Table I. Log $\mathrm{P}_{\text {EXP }}$ values of the synthesized compounds calculated by the standardization method in different solvents.

\begin{tabular}{|c|c|c|c|c|c|}
\hline Compound no. & $\mathrm{R}$ & $\log \mathrm{P}_{\text {acetone }}$ & $\log \mathrm{P}_{\text {acetonitrile }}$ & $\log \mathrm{P}_{1,4 \text {-dioxane }}$ & $\log \mathrm{P}_{\text {methanol }}$ \\
\hline 1 & 2,3-diF & 2.06 & 3.20 & 4.38 & 3.00 \\
\hline 2 & 2-Cl-3-OMe & 3.33 & 4.31 & 3.96 & 5.56 \\
\hline 3 & 2-Br-3-OH-4-OMe & 3.74 & 4.02 & 3.86 & 5.93 \\
\hline 4 & $2-\mathrm{F}-4-\mathrm{Br}$ & 4.38 & 4.11 & 4.81 & 6.56 \\
\hline 5 & 2,3-diOMe & 2.94 & 3.53 & 3.46 & 4.55 \\
\hline 6 & 3-Cl-4-OMe & 3.43 & 3.51 & 3.76 & 5.27 \\
\hline 7 & 3-Br-4-OMe & 3.69 & 3.63 & 3.94 & 5.39 \\
\hline 8 & $3-\mathrm{Br}-4-\mathrm{OH}$ & 2.23 & 3.50 & 2.26 & 2.35 \\
\hline 9 & 3-OEt-4-OH & 2.17 & 3.96 & 2.21 & 2.24 \\
\hline
\end{tabular}

$\mathrm{R}$, substituent; $\log \mathrm{P}_{\mathrm{EXP}}, \log \mathrm{P}$ values experimentally obtained using thin layer chromatography method.

Validation of Alternative Methods (EURL ECVAM), Database Service on Alternative Methods to Animal Experimentation (DB-ALM); http://cidportal.jrc.ec.europa.eu/ftp/jrc- opendata/ EURL-ECVAM/datasets/DBALM/LATEST/online/DBALM_ docs/17_P_MTT\%20Assay.pdf]. Cell viability was determined by a mitochondria-dependent reaction (reduction in mitochondrial dehydrogenase activity) based on the measurement of formazan production from the MTT salt and was expressed as the percentage of viable control cells. The compounds were dissolved in DMSO and subsequently diluted to the required concentration with the respective cell culture medium. The solutions were prepared ex tempore. The cells at a density of $1 \times 10^{5}$ cells $/ \mathrm{ml}$ in 96 -well plates were exposed to various concentrations of the tested compounds for $24 \mathrm{~h}$ at $37^{\circ} \mathrm{C}$. Following incubation, $10 \mu \mathrm{l}$ MTT solution $(5 \mathrm{mg} / \mathrm{ml})$ was added to each well of a microplate and incubated for $3 \mathrm{~h}$ at $37^{\circ} \mathrm{C}$. Subsequently, the culture medium was removed carefully from each well, and $100 \mu$ 1 DMSO was added. The absorbance of each well was measured at $550 \mathrm{~nm}$ using an ELx808IU automated absorbance microplate reader (BioTek Instruments, Inc.). Based on the MTT assay results, the $\mathrm{IC}_{50}$ values for the tested compounds were derived from the concentration-response curves (Table SIV). All parameters were evaluated in the presence of the solvent of benzenesulphonohydrazones 1-9, and there were no significant differences between the control cells and the solvent-treated cells. The final concentration of DMSO did not exceed $0.5 \%$ v/v. All experiments were performed $\geq 5$ times.

\section{Results}

Chemistry. New benzenesulphonylhydrazones 1-9 were obtained based on the condensation reaction of 4-methylbenzenesulphonohydrazide with appropriate aldehydes (Fig. 1). The synthesized compounds were stable solids and could be dissolved in DMSO at room temperature. The yields of the target products were between 31 and 55\%. The results of elemental analysis ( $\mathrm{C}, \mathrm{H}$ and $\mathrm{N}$ ) were within $\pm 0.4 \%$ of the calculated values. The spectral data (IR, ${ }^{1} \mathrm{H}$ NMR and ${ }^{13} \mathrm{C}$ NMR) confirmed successful synthesis of the new benzenesulphonohydrazide derivatives $1-9$. In the ${ }^{1} \mathrm{H}$ NMR spectra, characteristic singlet signals for $=\mathrm{CH}$ and $\mathrm{NH}$ groups were observed at $\delta$ 7.84-9.59 ppm and $\delta$ 10.57-11.75 ppm, respectively. Additionally, in the ${ }^{13} \mathrm{C}$ NMR spectra, the signal of the carbon atom of the $=\mathrm{CH}$ group was recorded at $\delta \sim 140 \mathrm{ppm}$. The reaction leading to the synthesis of target compounds is presented in Fig. 1. All the synthesized compounds were subjected to lipophilicity analysis and cytotoxicity assays.

Lipophilicity. The highest lipophilicity value was presented by compound 4 , which contained a 4-bromo-2-fluorophenyl substituent, irrespective of the organic modifier used (Table I). The introduction of other halogen atoms or the change of its position in the phenyl ring resulted in the decrease of lipophilicity values (compound 1). The replacement of the halogen atom by a methoxy group had a substantial impact on lipophilicity (compounds 2 and 5). The introduction of a hydroxy group and the position of the bromine atom in the phenyl ring had no impact on lipophilicity values (compounds 3 and 7). In the case of compounds 6 and 7, the type of halogen atom had no effect on lipophilicity. In addition, the replacement of the methoxy group by a hydroxy group visibly decreased lipophilicity (compounds 7 and 8), whereas the replacement of the bromine atom by an ethoxy group had no impact on the lipophilicity values (compounds 8 and 9) (Tables I and SIII).

Cytotoxicity. Based on our previous studies (24), the present study aimed to examine the potential of the newly synthesized benzenesulphonohydrazones 1-9 to inhibit the proliferation of selected cancer cell lines. Our previous study confirmed that the combination of a 1,3-thiazolidin-4-one scaffold with a hydrazide-hydrazone moiety exerts cytotoxic activity (24), in particular against HepG2 cells, which was also reported by He et al (37). The present study focused on the cytotoxic potential of a series of novel benzenesulphonohydrazide derivatives against HepG2, 769-P and H2170 cells.

Assessment of the in vitro cytotoxicity of the newly synthesized benzenesulphonohydrazide derivatives 1-9 was performed against human renal cell adenocarcinoma (769-P), human liver cancer (HepG2) and human squamous cell carcinoma of the lung (H2170) cell lines. As a normal reference cell line, Vero cells derived from the African green monkey kidney were used. 
Table II. Antiproliferative activity and selectivity of the newly synthesized benzenesulphonohydrazide derivatives.

\begin{tabular}{|c|c|c|c|c|c|c|c|c|}
\hline $\begin{array}{l}\text { Compound } \\
\text { no. }\end{array}$ & $\mathrm{R}$ & $\begin{array}{c}\mathrm{IC}_{50} \text { in } \\
\text { Vero, } \\
\mu \mathrm{M}\end{array}$ & $\begin{array}{c}\mathrm{IC}_{50} \text { in } \\
769-\mathrm{P}, \\
\mu \mathrm{M}\end{array}$ & $\begin{array}{l}\text { Selectivity } \\
\text { index }{ }^{\text {a }} \text { for } \\
769-\mathrm{P}\end{array}$ & $\begin{array}{c}\mathrm{IC}_{50} \text { in } \\
\text { HepG2, } \\
\mu \mathrm{M}\end{array}$ & $\begin{array}{l}\text { Selectivity } \\
\text { index }{ }^{\text {a for }} \\
\text { HepG2 }\end{array}$ & $\begin{array}{c}\mathrm{IC}_{50} \text { in } \\
\mathrm{H} 2170, \\
\mu \mathrm{M}\end{array}$ & $\begin{array}{c}\text { Selectiviy } \\
\text { index }{ }^{\text {a }} \text { for } \\
\mathrm{H} 2170\end{array}$ \\
\hline 1 & 2,3-diF & 259.00 & $>500.00$ & nd & $>500.00$ & nd & $>500.00$ & nd \\
\hline 2 & 2-Cl-3-OMe & $1,646.34$ & 67.56 & 24.37 & 160.46 & 10.26 & 501.55 & 3.28 \\
\hline 3 & 2-Br-3-OH-4-OMe & 396.24 & 144.29 & 2.75 & 200.08 & 1.98 & 387.24 & 1.02 \\
\hline 4 & $2-\mathrm{F}-4-\mathrm{Br}$ & 964.69 & 73.62 & 13.10 & 106.33 & 9.07 & 369.88 & 2.61 \\
\hline 5 & 2,3-diOMe & 108.93 & 1.94 & 56.15 & $>500.00$ & nd & $>500.00$ & nd \\
\hline 6 & 3-Cl-4-OMe & $1,457.83$ & 26.38 & 55.26 & 364.94 & 3.99 & 517.37 & 2.82 \\
\hline 7 & 3-Br-4-OMe & $1,208.49$ & 100.63 & 12.00 & $>500.00$ & nd & 314.55 & 3.84 \\
\hline 8 & $3-\mathrm{Br}-4-\mathrm{OH}$ & 157.20 & 74.54 & 2.11 & nd & nd & $>500.00$ & nd \\
\hline 9 & 3-OEt-4-OH & 146.63 & 54.23 & 2.70 & 285.95 & 0.51 & $>500.00$ & nd \\
\hline
\end{tabular}

$\mathrm{R}$, substituent; nd, not determined. ${ }^{\mathrm{a} C a l c u l a t e d}$ as the ratio between the $\mathrm{IC}_{50}$ values in the non-tumour cell line Vero and the respective cancer cell lines.

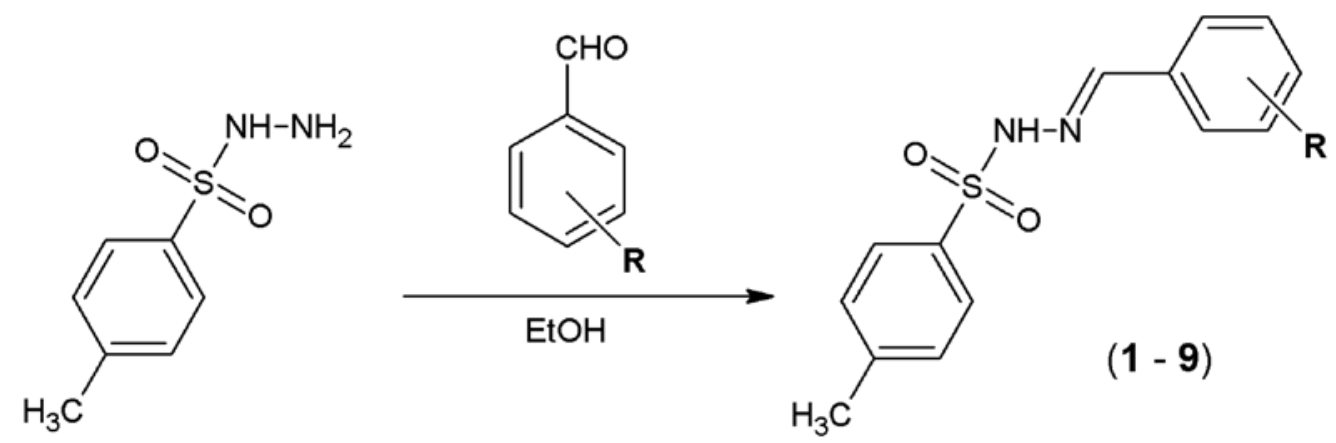

Figure 1. Synthesis of new benzenesulphonohydrazide derivatives. Compound 1: $\mathrm{R}=2,3-\mathrm{diF}$; Compound 2: $\mathrm{R}=2-\mathrm{Cl}-3-\mathrm{OMe}$; Compound 3: $\mathrm{R}=2-\mathrm{Br}-3-\mathrm{OH}-4-\mathrm{OMe}$; Compound 4: $\mathrm{R}=2-\mathrm{F}-4-\mathrm{Br}$; Compound 5: 2,3-diOMe; Compound 6: $\mathrm{R}=3$-Cl-4-OMe; Compound 7: $\mathrm{R}=3-\mathrm{Br}-4-\mathrm{OMe}$; Compound 8: $\mathrm{R}=3-\mathrm{Br}-4-\mathrm{OH}$; Compound 9: $\mathrm{R}=3-\mathrm{OEt}-4-\mathrm{OH}$.

Cell viability was evaluated by the MTT dye reduction assay, and the $\mathrm{IC}_{50}$ values for compounds $1-9$ (Table II) were determined based on the dose-response curves. Among the novel derivatives $1-9$, compound 5 was the most toxic toward 769-P cells, with an estimated $\mathrm{IC}_{50}$ of $1.94 \mu \mathrm{M}$ (Table II). However, the proliferation of the reference cells was also affected to a great extent $\left(\mathrm{IC}_{50}=108.93 \mu \mathrm{M}\right)$. In the HepG2 human liver cancer cell line, the lowest $\mathrm{IC}_{50}$ value was observed for compound 4 $(106.33 \mu \mathrm{M})$, and in human squamous cell carcinoma of the lung it was observed for compound $7(314.55 \mu \mathrm{M})$ (Table II). The normal kidney cells were the most resistant to cytotoxic activity of compound $2\left(\mathrm{IC}_{50}=1646.34 \mu \mathrm{M}\right.$, Table II), which inhibited the proliferation of 769-P cells $\left(\mathrm{IC}_{50}=67.56 \mu \mathrm{M}\right)$; however, its effect on HepG2 and $\mathrm{H} 2170$ cells was weak $\left(\mathrm{IC}_{50}\right.$ values of $160.46 \mu \mathrm{M}$ and $>500.00 \mu \mathrm{M}$, respectively, Table II). Compound 4 exhibited the most diverse antiproliferative potential in tumour cells with high selectivity (Table II). Compound 6 was the most toxic towards 769-P cells, with an estimated $\mathrm{IC}_{50}$ value of $26.38 \mu \mathrm{M}$, and it was characterized by high selectivity toward this cell line, with a selectivity index of 55.26 (Table II). Similarly, compound 7 was toxic mainly to 769-P cells with a selectivity index of 12.00 (Table II). As presented in Table II, the $\mathrm{IC}_{50}$ values determined for compounds 8 and 9 in 769-P-cells were satisfactory (74.54 and
$54.23 \mu \mathrm{M}$, respectively), whereas these values in the normal cell line were only 2-3-fold higher, suggesting poor selectivity (selectivity index, 2.11 and 2.70, respectively). Among the tested tumour cell lines, 769-P cells were the most sensitive, and $\mathrm{H} 2170$ cells were the least susceptible to the cytotoxic activity of the new benzenesulphonohydrazones.

\section{Discussion}

Based on the increasing incidence and mortality rates of cancer, patients with cancer still need new drugs with high efficacy and selectivity to minimize side effects. Hydrazide-hydrazones and benzenesulphonohydrazones exhibit anticancer activity $(11,12,38-42)$. Numerous studies have confirmed that these molecules displayed significant antiproliferative activity against the following cancer cell lines: Leukaemia (HL-60, SKW-3 and BV-173), lung (A549), liver (HepG2), renal (769-P), ovarian (SK-OV-3), breast (MDA-MB-231 and MCF-7), cervical (HeLa), skin (SK-MEL-2), colon (HCT15), gastric (Bc G-823) and pancreatic (MIA-PaCa-2) cancer (37,43-47).

The present study was a pilot study focused on the synthesis, lipophilicity and screening of the antiproliferative potential of 


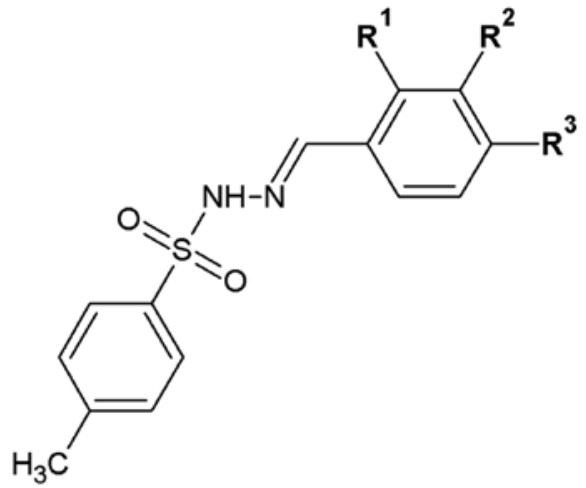

$(1-9)$

Figure 2. Effects of substituents on the antitumour activity of the synthesized benzenesulphonohydrazones.

newly developed benzenesulphonohydrazones. The results of the antitumour activity analysis demonstrated that the substitution with fluorine at the ortho-position and with bromine at the para-position of the phenyl ring of compound 4 provided the most diverse and significant cytotoxicity towards tumour cells, combined with an acceptable level of safety for normal cells. In HepG2 cells, the $\mathrm{IC}_{50}$ value and selectivity index indicated that compound 4 was the most cytotoxic and selective. The $\mathrm{IC}_{50}$ value of compound 4 in HepG2 cells was 2 -fold higher compared with that estimated for known cytostatics (cisplatin and 5-fluorouracil) $(48,49)$. Compound 4 also exhibited the highest lipophilicity, which suggested that high lipophilicity may be beneficial for antitumour activity.

Among the tested molecules, compound 7 was the most cytotoxic and selective in $\mathrm{H} 2170$ cells. However, when comparing the $\mathrm{IC}_{50}$ values estimated for the above compound with those of cisplatin, the activity of compound 7 appeared weak (50). In the present study, human squamous cell carcinoma of the lung cells was the least susceptible to the antiproliferative potential of the new benzenesulphonohydrazones.

The results of the present study demonstrated that compounds 2, 6 and 7 were cytotoxic and selective to cancer cells, in particular for renal cell adenocarcinoma. These compounds were substituted at the phenyl ring with chlorine or bromine atoms at the ortho- or meta-position, and with a methoxy group at the meta- or para-position of the phenyl ring. Considering the 769-P cell line, the 3-chloro-4-methoxyphenyl scaffold was demonstrated to be crucial. However, both ortho- and meta-methoxy groups at the phenyl ring of compound 5 provided a strong cytotoxic effect, but they also exerted this effect on normal cells. Nikolova-Mladenova et al (46) have reported the significance of the methoxy substituent at the phenyl ring of hydrazide-hydrazone derivatives for its cytotoxicity. In addition, the aforementioned study and another study (24) have reported that the hydroxy groups are responsible for the increase in cytotoxic potential towards cancer cells. This effect was also observed in the present study. The introduction of a hydroxy group at the meta- or para-position of the phenyl ring in compounds 3,8 and 9 provided satisfactory anticancer potential, but the selectivity was low. Among these compounds, compound 3 was the most selective, with the highest activity towards HepG2 and H2170 cells. Compound 3 was characterized by three substituents at the phenyl ring: 2-bromine, 3-hydroxy and 4-methoxy groups. In turn, the presence of two fluorine substituents at the ortho- and meta-position of the phenyl ring of compound 1 was demonstrated to be undesirable, since it exerted a toxic effect on normal cells, accompanied by a lack of anticancer activity. Fig. 2 demonstrates the effects of substituents of the phenyl ring on the antitumour activity of the synthesized benzenesulphonohydrazones 1-9. Substitution with fluorine $\left(\mathrm{R}^{1}\right)$ and bromine $\left(\mathrm{R}^{3}\right)$ atoms provided the most diverse and significant cytotoxicity to the tumour cells combined with safety for normal cells. Substitution with a bromine atom $\left(\mathrm{R}^{1}\right)$, hydroxy $\left(\mathrm{R}^{2}\right)$ and methoxy $\left(\mathrm{R}^{3}\right)$ groups increased activity against tumour cell lines HepG2 and $\mathrm{H} 2170$. Substitution with $\mathrm{OH}\left(\mathrm{R}^{2}\right.$ and $\left.\mathrm{R}^{3}\right)$ decreased selectivity. The results obtained in the present study emphasized the importance of particular substituents in the phenyl ring. However, the cancer cell line used also matters. For example, compound 5 substituted with two methoxy groups in the phenyl ring appeared to be most active against 796-P cell line with high selectivity, whereas HepG2 and H2170 cancer cells were not sensitive to this compound. The substituents affect not only the cytotoxic potency against cancer cells, but also the selectivity of the tested molecules. Admittedly, a non-human cell line (Vero) was used as a reference control to compare human cancer cell lines, which is a limitation to the present study. However, these cells are widely used by various research groups involved in the development of new biologically active molecules as a control cell line in in vitro cancer research (34-36).

In summary, the results of the present study demonstrated that the newly synthesized benzenesulphonohydrazones 1-9 exhibited antitumour potential, particularly compound 4, which was characterized by high, selective and diverse cytotoxicity to the tested cancer cell lines, whereas in the normal reference cells, its $\mathrm{IC}_{50}$ was determined to be higher. The compounds that were substituted with a halogen and methoxy group in the phenyl ring (compounds 2, 6 and 7) effectively inhibited the viability of 769-P cells and, to a lesser extent, that of HepG2 and H2170 cells, while exerting a limited effect on Vero cells. Across all compounds, the combination of fluorine and bromine substituents at the phenyl ring appeared to be the most advantageous, providing high cytotoxicity and selectivity towards tumour cells. Renal adenocarcinoma cells were the most sensitive to the antiproliferative potential of the newly developed molecules. Although this is a preliminary study, the obtained results suggested the direction of further research including the synthesis of new compounds of this chemical group. Even the preliminary results of the pilot attempt are relevant in the context of planning the synthesis of novel derivatives for pre-clinical studies. In addition, in our future work, other cancer lines will be tested as well as the mechanisms of cytotoxic activity of the most promising newly synthesized derivatives in order to examine and explain its antiproliferative potential. Our future studies will include the evaluation of apoptosis through various techniques such as the Annexin $\mathrm{V}$, western blot or Caspase Glo assays. Additionally, antiproliferative mechanism-focused experiments will also comprise the assessment of the effects of the new compounds on the cell 
cycle. Revealing the mechanisms responsible for the cytotoxic effect of the newly synthesized molecules may facilitate the development of new effective anticancer therapies.

\section{Acknowledgements}

Not applicable.

\section{Funding}

No funding was received.

\section{Availability of data and materials}

All the data generated and/or analysed during this study are included in this published article.

\section{Authors' contributions}

$Ł P$ designed the study, performed the synthesis of the benzenesulphonohydrazide derivatives, analysed the spectral data and wrote the first draft of the manuscript, with the exception of the lipophilicity and cytotoxicity sections. MGG, IPC, DNC and $\mathrm{MH}$ performed the cytotoxicity assays and wrote the cytotoxicity section of the manuscript. ABR performed the lipophilicity analysis of the obtained compounds and wrote the associated section of the manuscript. KP assisted with the synthesis of the benzenesulphonohydrazide derivatives. AG supervised and was involved in the conception of the lipophilicity analyses, helped with interpretation of lipophilicity data of synthesized compounds and revised critically section devoted to lipophilicity study in the final version of manuscript. JD supervised and was involved in the conception of the cytotoxicity analyses, helped with interpretation of cytotoxicity data of obtained derivatives and revised critically section devoted to cytotoxicity study in the final version of manuscript. MW supervised the synthesis and helped with the interpretation of the spectral data of the synthesized compounds. All authors read and approved the final manuscript.

\section{Ethics approval and consent to participate}

Not applicable.

\section{Patient consent for publication}

Not applicable.

\section{Competing interests}

The authors declare that they have no competing interests.

\section{References}

1. Li N, Zheng H, Zheng B, Chen C, Cai H and Liu M: Economic Evaluations of Immune Checkpoint Inhibitors for Patients with Non-Small Cell Lung Cancer: A Systematic Review. Cancer Manag Res 12: 4503-4518, 2020.

2. Duma N, Santana-Davila R and Molina JR: Non-Small Cell Lung Cancer: Epidemiology, Screening, Diagnosis, and Treatment. Mayo Clin Proc 94: 1623-1640, 2019.

3. Dela Cruz CS, Tanoue LT and Matthay RA: Lung cancer: Epidemiology, etiology, and prevention. Clin Chest Med 32: 605-644, 2011.
4. Ghouri YA, Mian I and Rowe JH: Review of hepatocellular carcinoma: Epidemiology, etiology, and carcinogenesis. J Carcinog 16: 1-25, 2017.

5. Meyers RL, Tiao G, de Ville de Goyet J, Superina R and Aronson DC: Hepatoblastoma state of the art: Pre-treatment extent of disease, surgical resection guidelines and the role of liver transplantation. Curr Opin Pediatr 26: 29-36, 2014.

6. Kabaria R, Klaassen Z and Terris MK: Renal cell carcinoma: Links and risks. Int J Nephrol Renovasc Dis 9: 45-52, 2016.

7. Tsai FJ, Liu X, Chen CJ, Li TM, Chiou JS, Chuang PH, Ko CH, Lin TH, Liao CC, Huang SM, et al: Chinese herbal medicine therapy and the risk of overall mortality for patients with liver cancer who underwent surgical resection in Taiwan. Complement Ther Med 47: 102213, 2019.

8. Liu Z, Suo C, Mao X, Jiang Y, Jin L, Zhang T and Chen X: Global incidence trends in primary liver cancer by age at diagnosis, sex, region, and etiology, 1990-2017. Cancer 126: 2267-2278, 2020.

9. Roseweir AK, Qayyum T, Lim Z, Hammond R, MacDonald AI, Fraser S, Oades GM, Aitchison M, Jones RJ and Edwards J: Nuclear expression of Lyn, a Src family kinase member, is associated with poor prognosis in renal cancer patients. BMC Cancer 16: 229-238, 2016.

10. Yuan ZX, Mo J, Zhao G, Shu G, Fu HL and Zhao W: Targeting strategies for renal cell carcinoma: From renal cancer cells to renal cancer stem cells. Front Pharmacol 7: 423-438, 2016.

11. Kamal A, Khan MN, Srinivasa Reddy K and Rohini K: Synthesis of a new class of 2-anilino substituted nicotinyl arylsulfonylhydrazides as potential anticancer and antibacterial agents. Bioorg Med Chem 15: 1004-1013, 2007.

12. El-Kerdawy MM, Ghaly MA, Darwish SA, Abdel-Aziz HA, Elsheakh AR, Abdelrahman RS and Hassan GS: New benzimidazothiazole derivatives as anti-inflammatory, antitumor active agents: Synthesis, in-vitro and in-vivo screening and molecular modeling studies. Bioorg Chem 83: 250-261, 2019.

13. Siemann S, Evanoff DP, Marrone L, Clarke AJ, Viswanatha T and Dmitrienko GI: $N$-arylsulfonyl hydrazones as inhibitors of IMP-1 metallo- $\beta$-lactamase. Antimicrob Agents Chemother 46: 2450-2457, 2002.

14. Backes GL, Neumann DM and Jursic BS: Synthesis and antifungal activity of substituted salicylaldehyde hydrazones, hydrazides and sulfohydrazides. Bioorg Med Chem 22: 4629-4636, 2014.

15. Neumann DM, Cammarata A, Backes G, Palmer GE and Jursic BS: Synthesis and antifungal activity of substituted 2,4,6-pyrimidinetrione carbaldehyde hydrazones. Bioorg Med Chem 22: 813-826, 2014.

16. Naeem S, Akhtar S, Asghar N, Sherwani SK, Mushtaq N, Kamil A, Zafar S, Arif M and Saify ZS: Antimicrobial and antioxidant screening of $\mathrm{N}^{\text {'-substituted sulphonyl and benzoyl }}$ derivatives of 4-Pyridine carboxylic acid hydrazide. Pak J Pharm Sci 28: 2129-2134, 2015.

17. Bhat M, Poojary B, Kumar SM, Hussain MM, Pai N, Revanasiddappa BC and Byrappa K: Structural, crystallographic, Hirshfeld surface, thermal and antimicrobial evaluation of new sulfonyl hydrazones. J Mol Struct 1159: 55-66, 2018.

18. Sondhi SM, Dinodia M and Kumar A: Synthesis, anti-inflammatory and analgesic activity evaluation of some amidine and hydrazone derivatives. Bioorg Med Chem 14: 4657-4663, 2006.

19. Popiołek Ł: Hydrazide-hydrazones as potential antimicrobial agents: Overview of the literature since 2010. Med Chem Res 26: 287-301, 2017.

20. Popiołek $Ł$ and Biernasiuk A: Design, synthesis, and in vitro antimicrobial activity of hydrazide-hydrazones of 2-substituted acetic acid. Chem Biol Drug Des 88: 873-883, 2016.

21. Popiołek $€$ and Biernasiuk A: Hydrazide-hydrazones of 3-methoxybenzoic acid and 4-tert-butylbenzoic acid with promising antibacterial activity against Bacillus spp. J Enzyme Inhib Med Chem 31 (S1): 62-69, 2016.

22. Popiołek $€$ and Biernasiuk A: Synthesis and investigation of antimicrobial activities of nitrofurazone analogues containing hydrazide-hydrazone moiety. Saudi Pharm J 25: 1097-1102, 2017.

23. Popiołek Ł, Biernasiuk A, Berecka A, Gumieniczek A, Malm A and Wujec M: New hydrazide-hydrazones of isonicotinic acid: Synthesis, lipophilicity and in vitro antimicrobial screening. Chem Biol Drug Des 91: 915-923, 2018.

24. Popiołek Ł, Piątkowska-Chmiel I, Gawrońska-Grzywacz M, Biernasiuk A, Izdebska M, Herbet M, Sysa M, Malm A, Dudka J and Wujec M: New hydrazide-hydrazones and 1,3-thiazolidin-4-ones with 3-hydroxy-2-naphthoic moiety: Synthesis, in vitro and in vivo studies. Biomed Pharmacother 103: $1337-1347,2018$. 
25. Nič M, Jirát J, Košata B, Jenkins A and McNaught A (eds.) Compendium of Chemical Terminology. IUPAC, Research Triagle Park, NC, 2009. https://doi.org/10.1351/goldbook.

26. Arnott JA, Kumar R and Planey SL: Lipophilicity indices for drug development. J App Biopharm Pharmacokin 1: 31-36, 2013.

27. Lipinski CA, Lombardo F, Dominy BW and Feeney PJ: Experimental and computational approaches to estimate solubility and permeability in drug discovery and development settings. Adv Drug Deliv Rev 46: 3-26, 2001

28. Arnott JA and Planey SL: The influence of lipophilicity in drug discovery and design. Expert Opin Drug Discov 7: 863-875, 2012.

29. Waring MJ: Lipophilicity in drug discovery. Expert Opin Drug Discov 5: 235-248, 2010.

30. Komsta, ,Skibiński R, Berecka A, Gumieniczek A, Radkiewicz B and Radoń M: Revisiting thin-layer chromatography as a lipophilicity determination tool - a comparative study on several techniques with a model solute set. J Pharm Biomed Anal 53: 911-918, 2010

31. Hawrył A, Popiołek Ł, Dobosz M, Pikula E and Waksmundzka-Hajnos M: RP-HPTLC determination of the lipophilicity of some new derivatives of thiosemicarbazide and 1,2,4-triazole of sulphanylacetic acid. Acta Chromatogr 22: $37-55,2010$.

32. TetkoIV,Gasteiger J, Todeschini R, Mauri A,Livingstone D, Ertl P, Palyulin VA, Radchenko EV, Zefirov NS, Makarenko AS, et al: Virtual computational chemistry laboratory - design and description. J Comput Aided Mol Des 19: 453-463, 2005.

33. VCCLAB: Virtual Computational Chemistry Laboratory, http://www.vcclab.org, 2005.

34. Aydın A, Korkmaz SA, Demir V and Tekin S: Anticancer and Cytotoxic Activities of $\left[\mathrm{Cu}\left(\mathrm{C}_{6} \mathrm{H}_{16} \mathrm{~N}_{2} \mathrm{O}_{2}\right)_{2}\right]\left[\mathrm{Ni}(\mathrm{CN})_{4}\right]$ and $\left[\mathrm{Cu}\left(\mathrm{C}_{6} \mathrm{H}_{16} \mathrm{~N}_{2} \mathrm{O}_{2}\right) \mathrm{Pd}(\mathrm{CN})_{4}\right]$ Cyanidometallate Compounds on HT29, HeLa, C6 and Vero Cell Lines. Anticancer Agents Med Chem 17: 865-874, 2017.

35. Gul HI, Yamali C, Bulbuller M, Kirmizibayrak PB, Gul M, Angeli A, Bua S and Supuran CT: Anticancer effects of new dibenzenesulfonamides by inducing apoptosis and autophagy pathways and their carbonic anhydrase inhibitory effects on hCA I, hCA II, hCA IX, hCA XII isoenzymes. Bioorg Chem 78: 290-297, 2018

36. Verma R, Bairy I, Tiwari M, Bhat GV and Shenoy GG: In silico studies, synthesis and anticancer activity of novel diphenyl ether-based pyridine derivatives. Mol Divers 23: 541-554, 2019.

37. He H, Wang X, Shi L, Yin W, Yang Z, He H and Liang Y: Synthesis, antitumor activity and mechanism of action of nove 1,3-thiazole derivatives containing hydrazide-hydrazone and carboxamide moiety. Bioorg Med Chem Lett 26: 3263-3270, 2016.

38. Abdel-Wahab BF, Awad GEA and Badria FA: Synthesis, antimicrobial, antioxidant, anti-hemolytic and cytotoxic evaluation of new imidazole-based heterocycles. Eur J Med Chem 46 $1505-1511,2011$
39. Mohamed Eissa AA, Soliman GA and Khataibeh MH: Design, synthesis and anti-inflammatory activity of structurally simple anthranilic acid congeners devoid of ulcerogenic side effects. Chem Pharm Bull (Tokyo) 60: 1290-1300, 2012.

40. el-Sabbagh OI and Rady HM: Synthesis of new acridines and hydrazones derived from cyclic beta-diketone for cytotoxic and antiviral evaluation. Eur J Med Chem 44: 3680-3686, 2009.

41. Lima LM, Frattani FS, Dos Santos JL, Castro HC, Fraga CA, Zingali RB and Barreiro EJ: Synthesis and anti-platelet activity of novel arylsulfonate - acylhydrazone derivatives, designed as antithrombotic candidates. Eur J Med Chem 43: 348-356, 2008.

42. Mashayekhi V, Haj Mohammad Ebrahim Tehrani K, Amidi S and Kobarfard F: Synthesis of novel indole hydrazone derivatives and evaluation of their antiplatelet aggregation activity. Chem Pharm Bull (Tokyo) 61: 144-150, 2013.

43. Alam MS, Choi SU and Lee DU: Synthesis, anticancer, and docking studies of salicyl-hydrazone analogues: A novel series of small potent tropomyosin receptor kinase A inhibitors. Bioorg Med Chem 25: 389-396, 2017.

44. El-Faham A, Farooq M, Khattab SN, Abutaha N, Wadaan MA, Ghabbour HA and Fun HK: Synthesis, characterization, and anti-canceractivity of somenew $N$ '-(2-oxoindolin-3-ylidene)-2-propylpentane hydrazide-hydrazones. Molecules 20: 14638-14655, 2015.

45. Kodisundaram P, Duraikannu A, Balasankar T, Sundarao Ambure P and Roy K: Cytotoxic and antioxidant activity of a set of hetero bicylic methylthiadiazole hydrazones: A structure-activity study. Int J Mol Cell Med 4: 128-137, 2015.

46. Nikolova-Mladenova B, Momekov G, Ivanov D and Bakalovaa A: Design and drug-like properties of new 5-methoxysalicylaldehyde based hydrazones with anti-breast cancer activity. J Appl Biomed 15: 233-240, 2017.

47. Taha M, Shah SAA, Afifi M, Zulkeflee M, Sultan S, Wadood A, Rahim F and Ismail NH: Morpholine hydrazone scaffold: Synthesis, anticancer activity and docking studies. Chin Chem Lett 28: 607-611, 2017.

48. Shang H, Li L, Ma L, Tian Y, Jia H, Zhang T, Yu M and Zou Z: Design and Synthesis of Molecular Hybrids of Sophora Alkaloids and Cinnamic Acids as Potential Antitumor Agents. Molecules 25: pii: E1168, 2020.

49. Tang BD, Xia X, Lv XF, Yu BX, Yuan JN, Mai XY, Shang JY, Zhou JG, Liang SJ and Pang RP: Inhibition of Orail-mediated $\mathrm{Ca}^{2+}$ entry enhances chemosensitivity of HepG2 hepatocarcinoma cells to 5-fluorouracil. J Cell Mol Med 21: 904-915, 2017.

50. Baharuddin P, Satar N, Fakiruddin KS, Zakaria N, Lim MN, Yusoff NM, Zakaria Z and Yahaya BH: Curcumin improves the efficacy of cisplatin by targeting cancer stem-like cells through p21 and cyclin D1-mediated tumour cell inhibition in non-small cell lung cancer cell lines. Oncol Rep 35: 13-25, 2016. 